\title{
Rapid kidney changes resulting from glycosphingolipid depletion by treatment with a glucosyltransferase inhibitor
}

\author{
Girja S. Shukla ', Arti Shukla ', Jin-ichi Inokuchi ${ }^{2}$ and Norman S. Radin ' \\ 'Mental Health Research Instituse, The Unilersity of Michigan, Ann Arhor, MI (LiS.A.) and 'Departmem of Binchemistry,

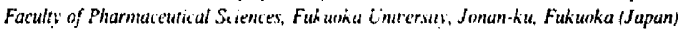

(Received 2) Septemher 1990)

\begin{abstract}
Key words: Ceramide; Glucosylceramide; Glucosylceramide glucosidase: Ceramide glucosyltransferase inhibition: I-Phenyl-2-decanoylamino-3-morpholino-1-propanol: t.-Cycloserine: Sphingolipid hydrolase: Sphingosine hiosynthesis inhibition: Kidney
\end{abstract}

The ceramide analog, D-threo-1-phenyl-2-decanoylamino-3-morpholino-1-propanol, inhibits the glucosylation of ceramide and thus, by virtue of the normal catabolism of the higher glucosphingolipids, leads to a general depletion of cellular glucolipids. In a previous study with chronic administration of this inhibitor in mice, it was found that the kidneys and liver, particularly the former, grew more poorly than the organs of control mice. This study shows that the inhibitor produces rapid decreases in glucolipid concentration in kidney which are maintained for at least 5 days without noticeable harm. The changes were enhanced by inclusion of L-cycloserine in the injection scheme. Cycloserine blocks ketosphinganine synthase and thus slows the synthesis of all sphingolipids. However, sphingomyelin levels did not drop significantly in this study. The glucosyltransferase inhibitor also produced a small decrease in kidney $\beta$-D-glucuronidase and distinct increases in the levels of glucocerebrosidase, galactocerebrosidase and sphingomyclinase. It also produced a small but distinet decrease in the level of glucosyltransferase, after a delay of a few hours, possibly becuase the inhibitor was metabolized to a covalently inactivating product. Comparison with kidney, liver and brain showed that the kidney was more sensitive to the action of the morpholino inhibitor.

\section{Introduction}

Glycosphingolipidoses are inborn errors of metabolism involving a major deficiericy in hydrolase activity. In most of these disorders, such as Gaucher, Fabry and Tay-Sachs diseases, the inadequate activity results in accumulation of the slowly catabolized lipid, evidently because direct feedback controls for slowing the synthesis do not exist. The suggestion has been made [1] that it might be possible to alleviate the symptoms of these disorders by using an enzyme inhibitor to slow the biosynthesis of glucosylceramide (GlcCer), the precursor of all the glucosphingolipids. This would allow the residual glycosidase activity to match the rate of

Abbreviations: CMH, ceramide monohexoside (mainly GlcCer): $\mathrm{CDH}$. ceramide dihexoside (lactosylceramide or LacCer); CS. I. cycloserine: GlcCer, glucosylceramide or glucocerebroside: PDMP. threo-1-phenyl-2-decanoylamino-3-morpholino-1-propanol.

Correspondence: N. Radin, Neuroscience Lab. Bldg.. 1103 E. Huron. Ann Arbor, MI 48104-1687, U.S.A synthesis and block the accumulation of the involved glucosphingolipids. Only a small reduction in the rate of synthesis would be necessary, since the rate of glucosphingolipids accumulation (in all but the infantile forms of these disorders) is fairly slow. We have developed an inhibitor of GlcCer synthase, D-threo-1-phenyl-2-decanoylamino-3-morpholino-1-propanol (D-PDMP), which works in cultured cells at the 5 to $20 \mu \mathrm{M}$ level to lower the levels of GlcCer [2-4]. As the higher glucosphingolipids undergo catabolism. their levels also decrease. The inhibitor acts in mice to retard or stop the growth of several kinds of inoculated tumors [5,6]. In the mice which had been freed of cancer cells, the animals appeared to grow normally after the treatment period was halted.

In tests with normal mice [5], it was found that 10 or 12 daily injections of D-PDMP led to reductions in liver and kidney size, the decrease being more persistent with the latter organ (as measured $40 \mathrm{~h}$ after halting the injections). Mouse kidney is noted for its high rate of excretion into urine of glucosphingolipids, as well as the involvement of some of these lipids in stage-specific 
development and sex differences, so it is possible that this organ is particularly sensitive to the rate of GlcCer synthesis [7]. Moreover. it was found with D- $\left[{ }^{3} \mathrm{H}\right] \mathrm{PDMP}$ that the highest concentration and longest persistence of the inhibitor appeared in kidney (Shukla. A. and Radin. N.S., unpublished data).

I.-Cycloserine (CS) has been found to block sphingosine synthesis and reduction in brain glycolipid content has been reported [8]. Its use in Gaucher disease. following the rationale des:ribed above, has also been suggested [9].

This paper describes additional effects of injecting normal mice with D.1.-PDMP (rather than the D-enanti(mes). with and without CS. Surprisingly rapid changes in the levels of the simple glucosphingolipids and sphingolipid hydrolases were found.

\section{Materials and Methods}

\section{Animals}

Mice of the ICR strain, from Harlan Sprague Dawley. were obtained at a weight of $20-22 \mathrm{~g}$ and kept in our animal room until they weighed about $28 \mathrm{~g}$. In most experiments, they were then sorted by weight into matched subgroups with a computer program which produced subgroups of similar mean weights and standard distributions [10]. Three subgroups of three each. or two subgroups of five each, were assigned at random into control or experimental groups. All mice were injected i.p. with isotonic saline containing the nonionic detergent. Myrj 52 (ICI Americas) at $12 \mathrm{mg} / \mathrm{ml}$. The experimental mice also received PDMP in the same medium. at $8 \mathrm{mg} / \mathrm{ml}$. with or without added $\mathrm{CS}$.

\section{Chemicals}

D,I.-, I)- and 1.-PDMP. $\mathrm{HCl}$ were prepared as described [2] and dissolved in Myrj-saline by warming to approx. $50^{\circ} \mathrm{C}$. Excess solution was stored in the cold and rewarmed as needed. L-Cycloserine free base and most reagents were from Sigma Chemical. Cycloserine solutions were made just before use. UDP-D-[6- $\left.{ }^{3} \mathrm{H}\right] \mathrm{glu}-$ cose was from Amersham.

\section{Enzrme assass}

The brain and liver and each pair of kidneys from each animal were stored at $-70^{\circ} \mathrm{C}$. then homogenized in 9 vols. of water shortly before being assayed. Aliquots of each homogerate were assayed in duplicate; since five mice were in each group, the data reported are the means of 10 observations. All enzyme assays were checked to make sure that the observed activities were proportional to tissue weight and length of incubation.

Glucocerebroridase was assayed with the fluorogenic substrate. NBD-GlcCer, with 0.1-0.2 $\mathrm{mg}$ of tissue in a total volume of $0.2 \mathrm{ml}$ containing GlcCer from Gaucher spleen. Triton X-100, sodium taurocholate and phosphate-citrate ( $\mathrm{pH} 5.0)$ [11].

Galactocerebrosidase was assayed similarly, with NBD-substituted cerebroside [12], using 0.2 to $0.5 \mathrm{mg}$ of tissue. Sphingmyelinase was assayed with 2-hexar decanoylamino-4-nitrophenylphosphorylcholine in 0.105 $\mathrm{ml}$ containing $1.5 \mathrm{mg}$ of tissue [13] and $\beta$-glucuronidase was assayed with phenolphthalein monoglucuronate [14]. using $0.5 \mathrm{mg}$ liver, $1 \mathrm{mg}$ kidney or $5 \mathrm{mg}$ brain per tube.

Ceramide : UDP-[ $\left.{ }^{3} \mathrm{H}\right]$ glucose glucosyltransferase was assayed by an improved method [15] which utilizes NAD to protect the nucleotide sugar against pyrophosphatase, an ultrasonic incubation bath and a new liquid/liquid solvent mixture for isolating the GlcCer formed. In the case of liver and brain synthases. ATP was used as the pyrophosphatase inhibitor.

\section{Lipid assayss}

The organs from the five mice in both subgroups were weighed immediately after dissection. then stored at $-70^{\circ} \mathrm{C}$ until analyzed. They were extracted with hexane-isopropyl alcohol [16] and the acidic lipids were removed by coiumn chromatography using chloroform/ methanol/water $(60: 30: 8)$ with Accell resin (a quaternary amine from Waters, Millipore Corp.) in the acetate form. Alkaline methanolysis in chloroform/ methanol/ $\mathrm{NaOH}$ decomposed the glycerolipids and a column of silica gel (Merck silica gel 60) separated the lipids into fractions for quantitative determination by TLC.

The ceramide fraction was chromatographed on 0.25 $\times 200 \times 200 \mathrm{~mm}$ silica gel plates (E. Merck) with hexane/chloroform $(1: 1)$, then with chloroform/ methanol/acetic acid $(91: 2: 3)$; the standards were 2.5 and $5 \mu \mathrm{g}$ of ceramide derived from beef brain sphingomyelin. The CMH-CDH fraction was chromatographed with chloroform/methanol/water $(60: 10: 1$, then with 24:7:1). The GlcCer standard, from Gaucher spleen, weighed 2.5 and $5 \mu \mathrm{g}$ and the lactosylceramide standard weighed 7.5 and $15 \mu \mathrm{g}$. The sphingomyelin fraction was chromatographed with chloroform/methanol/water $(60: 35: 8)$; the standards were 4 and $8 \mu \mathrm{g}$ of brain sphingomyelin. Each standard and each column fraction was applied to the plate in duplicate: a total of 13 samples per plate was applied with a streak applicator as $36 \mu l$ streaks.

The lipid hands were visualized by impregnating the plates with a modified charring reagent [17]. $100 \mathrm{~g}$ of $\mathrm{CuSO}_{4} \cdot 5 \mathrm{H}_{2} \mathrm{O}$ in conc. $\mathrm{H}_{3} \mathrm{PO}_{4} /$ water $/ \mathrm{MeOH}(100$ $750-400 \mathrm{ml}$ ). As noted by previous v skers [18]. kidney cerebroside $(\mathrm{CMH})$ is a mixture of monohexosylceramides formed from sphingosine, phytosphingosine. nonhydroxy fatty acids, 2-hydroxy fatty ucids, glucose and galactose, and thus forms several CMH bands. Only the fastest pair of TLC bands (long-chain and very-long- 
chain nonhydroxy acids) was quartitated but the decreases produced by PDMP and CS were visibly evident in the lower $\mathrm{CMH}$ bands too. (This suggests that the polar CMH's and less-polar CMHs have similar turnover rates.) A similar situation was seen for $\mathrm{CDH}$ but the mixture was not as complex.

The lipid bands were quantitated by reflected light videodensitometry. using an Apple Ile computer fitted with a digitizing board and stabilized with two types of voltage stabilizers in series. This is an improved vers on of a previously described device [19]. Each (quadruplicate) reading of a spot took $20-30 \mathrm{~s}$.

\section{Sturistical analysis}

The data were analyzed by one-way ANOVA and the Scheffé $F$-test. The differences between control and experimental groups significant at the $95 \%$ level are labeled with an asterisk.

\section{Results}

\section{Lipid changes}

In Expt. 1, 28-g mice were divided into three groups. each of which consisted of two five-mouse subgroups. The kidneys from each subgroup were pooled and e:tracted. Subgroups $A 1$ and $A 2$ were controls, injected i.p. only with Myrj in saline, $150 \mathrm{mg} / \mathrm{kg}$. Group B received the same injections, including D.L-PDMP (100 $\mathrm{mg} / \mathrm{kg}$ ). Group C was like B but $40 \mathrm{mg} / \mathrm{kg}$ of CS were included. $5 \mathrm{~h}$ after the injection. the mice were killed and assayed for lipid changes (Table I).
PDMP was seen to produce a rapid decrease in GleCer. indicating that this lipid has a high turnover rate in kidney. Since GleCer is formed by two mechanisms. ceramide glucosylation and hydrolysis of the higher glucosphingolipids, only the first of which is blocked by PDMP, it appears that the synthetic pathway must have been blocked rather completely and that the GlcCer seen was derived mainly from the second process. The lesser percentage decrease in LacCer is to be expected since it was still being synthesized from residual GlcCer, as well as by hydrolysis of the higher glucosphingolipids. While the average rates of :bsolute loss were similar for both glucosphingolipids ( $2.4 \mu \mathrm{g} / \mathrm{g}$ per $\mathrm{h}$ for $\mathrm{CMH}$ and PDMP alone. $2.7 \mu \mathrm{g} / \mathrm{g}$ per $\mathrm{h}$ for $\mathrm{CDH})$. this similarity is coincidental since the rates of loss depend on multiple factors - the rate of PDMP loss from kidney, the rates of $\mathrm{CMH}$ and $\mathrm{CDH}$ hydrolysis and synthesis. lie rates of excretion into urine and the differences in turnover between different glucosphingolipid suicellular pools.

Ceramide and sphingomyelin decreased only slightly in the mice treated with PDMP alone, but inclusion of CS - which slows the synthesis of all sphingolipids produced a marked decrease in ceramide level and augmented the effect of PDMP on LacCer.

In Exp!. 2. an attempt was made to increase and prolong the effects. Here there were two injections, 3.5 $\mathrm{h}$ apart and at a higher level. The dosages in the first injection were $125 \mathrm{mg} / \mathrm{kg}$ D.t.PDMP and $50 \mathrm{mg} / \mathrm{kg}$ $\mathrm{CS}$; in the second injection the PDMP dose was increased to $150 \mathrm{mg} / \mathrm{kg}$. All mice were killed $3.5 \mathrm{~h}$ after

\section{TABLE I}

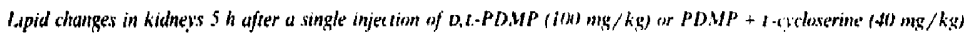

Data are the means of the dersitometric measurements of three TLC bands. The three hands were ohtained from the lipids extracted from 10 kidneys from five mice. The pairs of lines (such as Al and A2) were ohtuined from ! wo sets of five mice each: thus the calculated means and S.D. s are the result of measuring six TLC bands. Note the close agreement helween tach pair of five mice: this shows the effectiveness of the animal matcining priciss and the lipid technology.

\begin{tabular}{|c|c|c|c|c|}
\hline Treatment & $\begin{array}{l}\text { Ceramide } \\
(\mu \mathrm{g} / \mathrm{g})\end{array}$ & $\begin{array}{l}\text { CMH } \\
(\mu \mathrm{g} / \mathrm{g})\end{array}$ & $\begin{array}{l}\text { (DH } \\
(\mu \mathrm{g} / \mathrm{g})\end{array}$ & $\begin{array}{l}\text { Sphingomyelin } \\
(\mathrm{mg} / \mathrm{g})\end{array}$ \\
\hline \multicolumn{5}{|l|}{$\overline{C o n t r o l s}$} \\
\hline Al & 104.2 & 32.1 & 9.9 & 2.77 \\
\hline A2 & 106.7 & 35.5 & $0: x$ & 3.05 \\
\hline Mean \pm S.D. & $105.4 \pm 1.8$ & $33.8 \pm 1.9$ & $91.4 \pm 1.11$ & $2.91 \pm 0.16$ \\
\hline \multicolumn{5}{|l|}{ PDMP } \\
\hline BI & 93.8 & 20.7 & 79.5 & 2.62 \\
\hline B2 & 99.0 & 22.9 & 75.9 & 2.82 \\
\hline Mean \pm S.D. & $96.4 \pm 3.0$ & $21.8 \pm 1.3$ & $77.7 \pm 2.2$ & $2.72 \pm 0.12$ \\
\hline (\% change) & $(-9 \%)^{*}$ & $(-35 \%) *$ & $(-15)^{*}$ & $(-7)$ \\
\hline \multicolumn{5}{|l|}{ PDMF + CS } \\
\hline $\mathrm{Cl}$ & 81.1 & 22.1 & 70.2 & 2.84 \\
\hline $\mathrm{C} 2$ & 85.8 & 24.7 & 6.3 .4 & 2.69 \\
\hline Mean \pm S.D. & $83.5 \pm 2.7$ & $23.4 \pm 1.4$ & $66.7 \pm 3.8$ & $2.76 \pm 0.09$ \\
\hline (号 change) & $(-21)$ & $(-31 \%)$ & $(-279)$ & $\left(-5^{\bar{T}}\right)$ \\
\hline
\end{tabular}

Significintly different Iroin the controls. 
TABLE II

Lipid changes wi kidneys 7 h after the first of two injections of D.I.PDMP or PDMP + L-cycloserine or cycloserine alone

Data are the means of the densitometric measurements of three TLC bands. The three bands were obtained from the lipids extracted from 10 kidnevs from five mice. Groups 1 and 2 are subgroups of five mice each. as in Table I. See Results for details of injections.

\begin{tabular}{|c|c|c|c|c|}
\hline $\overrightarrow{\text { Treatment }}$ & $\begin{array}{l}\text { Ceramide } \\
(\mu \mathrm{g} / \mathrm{g})\end{array}$ & $\begin{array}{l}\mathrm{CMH} \\
(\mu \mathrm{g} / \mathrm{g})\end{array}$ & $\begin{array}{l}\mathrm{CDH} \\
(\mu \mathrm{g} / \mathrm{g})\end{array}$ & $\begin{array}{l}\text { Sphingomyelir } \\
(\mathrm{mg} / \mathrm{g})\end{array}$ \\
\hline \multicolumn{5}{|l|}{ Controls } \\
\hline A1 & 107.1 & 34.1 & 85.2 & 2.57 \\
\hline $\mathrm{A} 2$ & 108.7 & 33.8 & 88.3 & 2.76 \\
\hline Mean \pm S.D. & $107.9 \pm 1.3$ & $33.9 \pm 0.3$ & $86.8 \pm 1.9$ & $2.66 \pm 0.14$ \\
\hline \multicolumn{5}{|l|}{ PDMP } \\
\hline$B I$ & 102.5 & 24.2 & 71.5 & 2.91 \\
\hline 132 & 95.2 & 23.6 & 70.8 & 2.70 \\
\hline $\begin{array}{l}\text { Mean \&: S.D. } \\
\text { (Te change) }\end{array}$ & $\begin{array}{l}98.8 \pm 4.1 \\
(-8 \%)^{*}\end{array}$ & $\begin{array}{l}23.9 \pm 0.4 \\
(-30 \%)^{*}\end{array}$ & $\begin{array}{l}71.1 \pm 1.1 \\
(-18 \%)^{*}\end{array}$ & $\begin{array}{l}2.81+0.14 \\
(+5 \%)\end{array}$ \\
\hline \multicolumn{5}{|l|}{$\mathrm{PDMP}+\mathrm{CS}$} \\
\hline $\mathrm{Cl}$ & 54.8 & 19.2 & 56.6 & 2.52 \\
\hline $\mathrm{C} 2$ & 55.7 & 19.5 & 56.1 & 2.57 \\
\hline $\begin{array}{l}\text { Mean } \pm S . D \\
\text { (re change) }\end{array}$ & $\begin{array}{l}55.2 \pm 0.7 \\
(-49 \%)^{*}\end{array}$ & $\begin{array}{l}19.4 \pm 0.3 \\
(-43 \%)\end{array}$ & $\begin{array}{l}56.4 \pm 0.7 \\
(-35 \%)^{*}\end{array}$ & $\begin{array}{l}2.54 \pm 0.10 \\
(-5 \Phi)\end{array}$ \\
\hline \multicolumn{5}{|l|}{ Cycloserine } \\
\hline D1 & 55.0 & 32.2 & 80.2 & 2.49 \\
\hline D2 & 56.1 & 32.4 & 76.9 & 2.51 \\
\hline $\begin{array}{l}\text { Mean } \pm S . D \text {. } \\
\text { (\% change) }\end{array}$ & $\begin{array}{c}55.5 \pm 0.9 \\
(-49 \%)^{*}\end{array}$ & $\begin{array}{l}32.3 \pm 0.3 \\
(-5 \%)\end{array}$ & $\begin{array}{l}78.5 \pm 2.1 \\
(-9 \%)^{*}\end{array}$ & $\begin{array}{l}2.50 \pm 0.10 \\
(-6 \%)\end{array}$ \\
\hline
\end{tabular}

* Significantly different from the controls.

TABLE III

Lipid changes in kidneys of $25.5 \mathrm{~g}$ mice, injected Iwice a day, at 9:00 a.m. and 5:00 p.m., for 4 days. After a finat injection in the marning of the fifth day, the mice were killed $6.5 \mathrm{~h}$ later. The dosages wer? changed each day as follows: D.L-PDMP was $150,120,100,90 \mathrm{and} 90 \mathrm{mg} / \mathrm{kg}$ each day; CS was $50,40,3 ., 30$ and $30 \mathrm{mg} / \mathrm{kg}$ each day

Data are the means of the densitometric measurements of three TLC bands as described in Table I.

\begin{tabular}{|c|c|c|c|c|}
\hline Treatment & $\begin{array}{l}\text { Ceramide } \\
(\mu \mathrm{g} / \mathrm{g})\end{array}$ & $\begin{array}{l}\text { CMH } \\
(\mu \mathrm{g} / \mathrm{g})\end{array}$ & $\begin{array}{l}\text { CDii } \\
(\mu g / g)\end{array}$ & $\begin{array}{l}\text { Sphingomyelin } \\
(\mathrm{mg} / \mathrm{g})\end{array}$ \\
\hline \multicolumn{5}{|l|}{ Controls } \\
\hline Al & 108.3 & 32.4 & 81.6 & 2.70 \\
\hline A2 & 102.0 & 33.2 & 85.4 & 2.76 \\
\hline Me:an \pm S.D. & $105.6 \pm 3.6$ & $32.8 \pm 0.5$ & $83.5 \pm 2.3$ & $2.73 \pm 0.08$ \\
\hline \multicolumn{5}{|l|}{ PDMP } \\
\hline B] & 79.9 & 22.7 & 72.6 & 2.89 \\
\hline B2 & 82.4 & 22.7 & 76.4 & 2.80 \\
\hline $\begin{array}{l}\text { Mean } \pm \text { S.D. } \\
\text { (F change) }\end{array}$ & $\begin{array}{l}81.3 \pm 1.6 \\
(-23 \%)^{*}\end{array}$ & $\begin{array}{l}22.7 \pm 0.3 \\
(-31 \%)\end{array}$ & $\begin{array}{l}74.5 \pm 2.3 \\
(-11 \%)=\end{array}$ & $\begin{array}{l}2.85 \pm 0.10 \\
(+4.5)\end{array}$ \\
\hline \multicolumn{5}{|l|}{$\mathrm{PDMP}+\mathrm{CS}$} \\
\hline $\mathrm{Cl}$ & 58.8 & 15.4 & $\$ 7.2$ & 2.85 \\
\hline $\mathrm{C} 2$ & $\$ 24$ & 17.5 & 54.5 & 2.88 \\
\hline $\begin{array}{l}\text { Meun } \pm \text { S.D. } \\
\text { (F change) }\end{array}$ & $\begin{array}{l}55.6 \pm 3.6 \\
(-47 \%)^{*}\end{array}$ & $\begin{array}{l}16.4 \pm 1.2 \\
(-50 \%)^{*}\end{array}$ & $\begin{array}{l}55.9 \pm 1.6 \\
(-33 \%)^{*}\end{array}$ & $\begin{array}{l}2.86 \pm 0.09 \\
(+5 \%)\end{array}$ \\
\hline \multicolumn{5}{|l|}{ Cycloserine } \\
\hline D1 & 62.0 & 31.5 & 81.2 & 2.59 \\
\hline D2 & 60.9 & 33.0 & 83.2 & 2.61 \\
\hline $\begin{array}{l}\text { Mean } \pm \text { S.D } \\
\text { (T change) }\end{array}$ & $\begin{array}{c}61.4 \pm 1.0 \\
(-42 \%)^{*}\end{array}$ & $\begin{array}{l}32.3 \pm 1.0 \\
(-2 \mathscr{X})\end{array}$ & $\begin{array}{l}82.2 \pm 1.4 \\
(-2 \%)\end{array}$ & $\begin{array}{l}2.60 \pm 0.04 \\
(-5 \%)\end{array}$ \\
\hline
\end{tabular}

* Significantly different from the controls. 
the last injection. An additional group. given $\mathrm{CS}+\mathrm{Myrj}$. was included in this experiment.

The results were similar to those of Expt. 1 and it was now apparcnt that the loss of ceramide was primarily due to the ability of CS to block sphingosine synthesis (Table II). This time, with the longer exposure to higher doses of inhibitors. LacCer decreased even more. The effect of CS on the ceramide level was also distinatly greater.

While the kidney weights in Expt. 1 had not decreased significantly, here group $C$ had kidneys that were $14 \%$ smaller and group D kidneys were $10 \%$ smaller $(P<0.05, n=10)$.

Similar decreases in $\mathrm{CMH}$ and synergistic action were seen in liver after subcutaneous injection of $D$ PDMP and CS as the stearate salts together with Myrj (unpublished data). In one such experiment, the concentration of total lipids in liver also decreased $(10 \%$ with D-PDMP, 21\% with PDMP + CS, 23\% with CS alone). The opposite effect on total liver lipids was produced by elevating the organ's GlcCer level, especially when the GlcCer was protected against glucosidase action by conduritol B epoxide [20].

In Expt. 3, an attempt was made to see whether the lipid changes could be maintained over a period of time or whether some adaptive metabolic normalization occurred when the two inhibitors were injected twice a day. At the dose levels used (Table III), the treated mice lost weight and the dosages were accordingly reduced each day. By the end of the fifth day, the average decreases in body weight were $18 \%$ in the PDMP group (B). $22 \%$ in the PDMP-CS group (C) and $14 \%$ in the CS group (D), significant differences when compared with the control mice. The kidney weights decreased proportionately.

The changes in lipid concentrations were similar to those seen in Table 11, except for the enhanced lowering effect of PDMP on ceramide. Evidently. the enzyme blockages and their sequelae could be maintained over a longer period of time, making the therapeutic use of the two inhibitors even more promising.

Expt. 4 was run to determine whether a lower dose of PDMP could be used and whether the L-enantiomer might interfere with the action of the p-enantiomer (the actual inhibitor of GlcCer synthase). The protocol was similar to that of Expt. 2 (a total of $7 \mathrm{~h}$ of exposure to PDMP) but three three-mouse subgroups were used instead of two five-mouse subgroups to produce the reported values. It was evident that reducing the dosage of D,L-PDM:P reduced the magnitude of the loss in GicCer and lactosylceramide (Table IV). In this experiment, the change in ceramide level was not as large as before. D-PDMP. at $80 \mathrm{mg} / \mathrm{kg}$. produced the equivalent effect of $160 \mathrm{mg} / \mathrm{kg}$ of the racemic mixture. L-PDMP produced some decreases but the changes were not statistically significant. We conclude that ihe use of the (cheaper) D.L-mixture gives results that are similar to those of D-PDMP in shori-term experiments.

\section{Enzlme changes}

When Glc Cer levels were increased in mice by blocking glucosidase with conduritol B epoxide. the levels of several enzymes changed. $\beta$-Glucuronidase decreased in mouse liver but increased in brain [14]. Other enzyme changes have been reported in brain [21] and. with a different glucosidase inhibitor, in cultured neuronal cells [22]. Marked elevations of certain apparently-unrelated enzymes in spleen and plasma occur in Gaucher patients [23]. It therefore seemed appropriate to seek enzyme changes in mice whose GlcCer level had been lowered, especially enzymes involving sphingolipids.

Expt. 5 was run with the protocol used in Expt. 2.

TABLE IV

Lipid changes in kidney.s. $7 \mathrm{~h}$ after the first if iwo injections of D.L. D- or L.PDMP

Data are the means of the densitometric measurements \pm S.D. of six TLC bards derived from three subgroups of three mice tach. analyzed in duplicale.

\begin{tabular}{|c|c|c|c|c|}
\hline Treatment & $\begin{array}{l}\text { Ceramide } \\
(\mu \mathrm{g} / \mathrm{g})\end{array}$ & $\begin{array}{l}\text { CMH } \\
(\mu g / g)\end{array}$ & $\begin{array}{l}\text { CDH } \\
(\mu \mathrm{g} / g)\end{array}$ & $\begin{array}{l}\text { Sphingomyclin } \\
\text { (mg/g) }\end{array}$ \\
\hline Controls & $112 \pm 4$ & $37.1 \pm 0.7$ & $97 \pm 4$ & $2.85 \pm 0.13$ \\
\hline $\begin{array}{l}\text { D,1-PDMP } 160 \mathrm{mg} / \mathrm{kg} \\
\text { ( } \% \text { change) }\end{array}$ & $\begin{array}{l}108 \pm 5 \\
(-4 \%)\end{array}$ & $\begin{array}{l}26.8 \pm 1.2 \\
(-28 \%)^{*}\end{array}$ & $\begin{array}{l}84+5 \\
(-13 x)=\end{array}$ & $\begin{array}{l}2.98 \pm 0.16 \\
(+57)\end{array}$ \\
\hline $\begin{array}{l}\text { D.t-PDMP } 80 \mathrm{mg} / \mathrm{kg} \\
\text { ( } \% \text { change) }\end{array}$ & $\begin{array}{l}111 \pm 3 \\
(-10)\end{array}$ & $\begin{array}{l}30.3 \pm 0.5 \\
(-18.0)\end{array}$ & $\begin{array}{l}99 \pm 6 \\
(+28)\end{array}$ & $\begin{array}{l}3.03 \pm 0.19 \\
(+67)\end{array}$ \\
\hline $\begin{array}{l}\text { D-PDMP } 80 \mathrm{mg} / \mathrm{kg} \\
\text { (\% change) }\end{array}$ & $\begin{array}{l}122 \pm 4 \\
(+95)\end{array}$ & $\begin{array}{l}27.5 \pm 0.8 \\
(-26 \%)^{*}\end{array}$ & $\begin{array}{l}95 \pm 3 \\
(+28)\end{array}$ & $\begin{array}{l}3.05 \pm 0.20 \\
(+7 \%)\end{array}$ \\
\hline $\begin{array}{l}\text { L.PDMP } 80 \mathrm{mg} / \mathrm{kg} \\
\text { (\% change) }\end{array}$ & $\begin{array}{l}104 \pm 4 \\
(-7 \%)\end{array}$ & $\begin{array}{l}36.4 \pm 1.5 \\
(-2 \%)\end{array}$ & $\begin{array}{l}90 \pm 4 \\
(-78)\end{array}$ & $\begin{array}{l}2.73 \pm 0.18 \\
(-58)\end{array}$ \\
\hline
\end{tabular}

\footnotetext{
- Significantly different from control mice.
} 
but only five mice were used per group and the pooled kidneys of each mouse were assayed for three sphingolipid hydrolases and glucuronidase. Cycloserine produced no significant changes (Table $V$ ) but PDMP produced distinct increases in the sphingolipid hydrolases and a decrease in glucuronidase.

Expt. 6 was run to see if PDMP exerted any effect on the level of GlcCer synthase (it is not uncommon for an organism to respond to an inhibitor by synthesizing additional enzyme molecules). Five groups of mice (five mice per group, average wt. $36.1 \pm 1.2 \mathrm{~g}$ ) were injected once with D-PDMP, at $80 \mathrm{mg} / \mathrm{kg}$ i.p. and killed $1 / 3,1$, 3.8 or $24 \mathrm{~h}$ after the injection. Three organs from each mouse were separately assayed for glucosyltransferase activity. Five control mice received only the Myrj 52 injection. For the early time points. it was necessary to use relatively small portions of tissue to dilute out the PDMP still in the tissue. Thus, the observed activities reflect the actual amount of enzyme activity in the tissues rather than their degree of inhibition in vivo. Tests with animals injected with Myrj alone showed that it had no effect.

No significant change was seen in the transferase level during the first hour after PDMP injection (Fig. 1): by 4 and $8 \mathrm{~h}$, kidney showed significant decreases in enzyme level but this normalized by $24 \mathrm{~h}$. Liver also showed a significant loss of enzyme by $3 \mathrm{~h}$ and also normalized. Brain did not show any significant differences. A study of $\mathrm{D}-\left[1-{ }^{3} \mathrm{H}\right] \mathrm{PDMP}$ metabolism (Shukla. A. and Radin. N.S., unpublished data) has revealed that the inhibitor is rapidly metabolized and excreted so one might expect to see no inductive effects, but a small proportion of the compound was converted to labeled water. Since the label was on carbon- 1 of the inhibitor (the hydroxylic carbon), it is likely that it was converted to water by oxidation to the ketonic analog. The ketone (2-decanoylamino-3-morpholinopropiophenone) is an inactivating inhibitor of the glucosyltransferase [1]. It appears from these observations

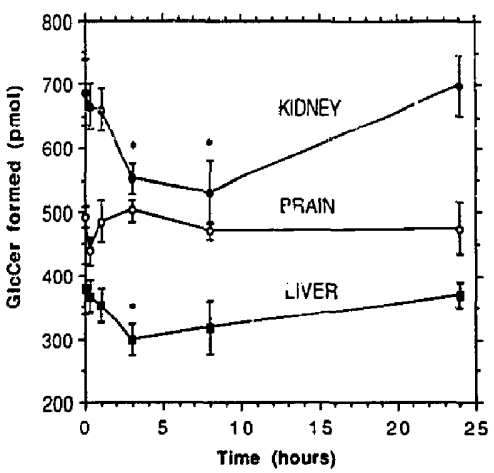

Fig. 1. Glucosyltransierase activity of tissues from five mice (per time point) injected once with D.PDMP. $80 \mathrm{mg} / \mathrm{kg}$ and $120 \mathrm{mg} / \mathrm{kg}$ of the detergent. Myrj 52. The tissue from each animal was homogenized (both kidneys were pooled) and portions assayed for activity, using octunoyl sphingosine as glucose acceptor. The error bars show the S.D. The zero time activity is based on mice injected only with Myrj in saline and killed $3 \mathrm{~h}$ later. ${ }^{*}$ Significantly different from the controls at $95 \%$.

that the effective enzyme activity in vivo is lowered by PDMP in two ways, by direct contact and resultant inhibition and by chemical inactivation of some of the enzyme. The recovery with time to normal transferase levels (Fig. 1) is probably due to resynthesis of new enzyme molecules. In a previous study in mice with a single injection of ketonic form of PLMP [24], the glucosyltransferase level in liver rebounded to $20 \%$ above normal within $24 \mathrm{~h}$.

Expt. 7, run as in Expt. 6 with a 7-h exposure to isomeric forms of PDMP, produced changes in GlcCer glucosyltransferase similar to those seen in Fig. 1. LPDMP had no effect and the brain enzyme showed no changes with any of the drugs used (unpublished data). From tha latter observation, the observed decreases in kidney enzyme level (Expt. 6), and the finding that D-PDMF readily penetrates the brain (Shukla, A. and

\section{TABIF. V}

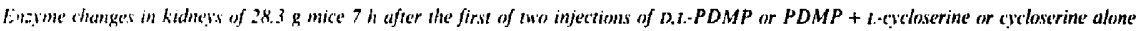
Ditla are the means and S.D. s ohtained from duplicate assays of the two kidneys homogenized from each of the five mice per group. The ellzyme activities are in $\mathrm{nmol} / \mathrm{h}$ per $\mathrm{mg}$ tissue. Protocol described in text.

\begin{tabular}{|c|c|c|c|c|}
\hline Treatment & Glucosidase & Gajactosidase & Sphingomyelinase & Glucuronidase \\
\hline Controls & $23.9 \pm 0.8$ & $11.8 \pm 0.5$ & $7.31 \pm 0.97$ & $12.3 \pm 0.3$ \\
\hline $\begin{array}{l}\text { PDMP } \\
\text { ('; change) }\end{array}$ & $\begin{array}{l}29.8 \pm 2.3 \\
(+25 \%)^{*}\end{array}$ & $\begin{array}{l}15.8 \pm 1.3 \\
(+349)\end{array}$ & $\begin{array}{l}9.70 \pm 1.2 \\
(+339)\end{array}$ & $\begin{array}{l}10.9 \pm 0.5 \\
(-119)^{*}\end{array}$ \\
\hline $\begin{array}{l}\text { PIDMU + (S } \\
\text { (r' change) }\end{array}$ & $\begin{array}{l}28.9 \pm 0.7 \\
(+217)^{*}\end{array}$ & $\begin{array}{l}16.4 \pm 0.4 \\
(+38 \%)\end{array}$ & $\begin{array}{l}16.24 \pm 1.6 \\
(+40 \%) *\end{array}$ & $\begin{array}{l}10.9 \pm 0.4 \\
(-11 \%)^{*}\end{array}$ \\
\hline $\begin{array}{l}\text { (ycioserine } \\
\text { (ri change) }\end{array}$ & $\begin{array}{l}24.4 \pm 1.1 \\
(+2 \%)\end{array}$ & $\begin{array}{l}12.7 \pm 0.8 \\
(+8 \mathrm{i})\end{array}$ & $\begin{array}{l}7.22 \pm 0.91 \\
(-1+1)\end{array}$ & $\begin{array}{l}12.4+0.4 \\
(+1 \%)\end{array}$ \\
\hline
\end{tabular}

\footnotetext{
* Significantly different from control mice.
} 
Radin. N.S.. unpublished data). it appears likey that the brain does not oxidize PDMP to the ketone. Liver and kidney both showed decreased levels of glucosyltransferase specific activity when $160 \mathrm{mg} / \mathrm{kg}$ of D.l.PDMP or $80 \mathrm{mg} / \mathrm{kg}$ of D-PDMP was injected but the lower dose. $80 \mathrm{mg} / \mathrm{kg}$ of D.L.PDMP. produced only a small, statistically nonsignificant decrease.

Glucocerebrosidase, as in Expt. 5, was significantly increased in kidney but not in liver or brain. Unexpectedly. the increase appeared with all mice injected with PDMP, including the $80 \mathrm{mg} / \mathrm{kg}$ doses of D.L.- and L-PDMP. The same was found for sphingomyelinase and galactosylceramide $\beta$-galactosidase and. as before. the increases were larger than for glucosidase. $\beta$-Dglucuronidase was slightly but significanily decreased only in kidneys of mice injected with $160 \mathrm{mg} / \mathrm{kg}$ of D.L-PDMP. Thus. it appears again that kidney is somewhat more sensitive to PDMP than brain or liver. A direct elfect of D,L-PDMP on these enzymes was ruled out by adding 1 to $100 \mu \mathrm{M}$ PDMP to the homogenates; no effect was seen (except for GlcCer synthase).

\section{Discussion}

Our finding that CS and PDMP work synergistically to lower GlcCer levels suggests that a mixture of the two would be even more useful in the proposed applications listed in the Introduction. Both inhibitors enter the brain (Shukla, A. and Radin. N.S., unpublished data and Ref. 9) so they shculd so cffectivi in preventing the brain deterioration seen in some sphingolipidosis patients. CS also inhibits a variety of pyridoxal-dependent enzymes to some extent. which might limit its usefulness for long-term therapy. The enantiomer of CS. Dcycloserine, is used clinically as an antibiotic to only a minor degree, possibly because of this effect on pyridoxal enzymes. L-CS has been used in chronic doses in rabbits [25] and in mice [9] to slow sphingosine synthesis.

While the enantiomer in D.t.-PDMP active against GlcCer synthase is the p-isomer. L-PDMP has been found to lower glucosphingolipid levels in cultured cells. although it is not as dose-effective as the D-isomer [4]. Since our findings do not reveal any serious harmful effects of the racemic mixture, it is thus reasonable to use the cheaper mixture in vivo. In fact, the t-enantiomer appears to exert its glucosphingolipids-lowering effect by slowing the synthesis of ceramide (compare the data in Table IV). Although L-PDMP did not produce a significant decrease in that experiment. the decrease was consistent with the decrease seen in the sphingomyelin level. In this experiment, conversely. DPDMP produced a sigrificant rise in ceramide level and a nonsignificant rise in sphingomyelin. Similarly, DPDMP has caused an increased amount of radioactivity (from labeled precursor) in the ceramide of cultured cells $[4,26]$. Thus, the 1-enantiomer in the racemic mixture may counteract the tendency of D-PDMP to cause an accumulation of ceramide and stimulate sphingomyelin formation. The data in Tables I-III show that the racemic mixture produced a significant drop in ceramide level, possibly because of the t.-isomer. We plan to test this interpretation of the data by direct assay of ceramide synthases in vitro.

The speed with which the kidnevs lost glucosphingolipids after treatment with CS and PDMP points to a rapid turnover rate for these lipids. Glucosphingolipids of kidney. especially in male mice, are lost not only by hydrolysis but also by excretion into urine 171 . It is possible that our observed changes might not be so evident in female mice or in animals (such as humans) in which the urinary excretion of glucosphingolipids is somewhat slower.

The unexpected observation that glucosphingolipids depletion caused an elevation in GlcCer glucosidase specific activity may mean that PDMP lowers glucosphingolipids levels not only by slowing GlcCer synthesis but also by accelerating the normal hydrolytic loss of Glocer from ridney.

The elevations in the three sphingolipid hydrolases that were produced by treatment with PDMP, hut not by CS (Table $V$ ), are intriguing but the causal relationship is not obvious. Perhaps this relationship is to be found in the observations that: (a) the hydrolase stimulating proteins acting on GlcCer glucosidase. galactosyleeramide galactosidase, and sphingomyelinase are all derived from a single precursor protein [27]: and that (b) the level of glucosidase stimulator in mice (saposin C) rises when the GlcCer leve] rises [20]. The activators for all three enzymes accumulate in patients exhibiting a high level of GicCer [27].

The decrease in glucuronidase that we obtained by decreasing GlcCer levels is mirrored by the elevation seen in platelets of patients with Gaucher disease [28]. While these changes suggest a close relation to GlcCer levels. our previous studies, in which the level of GlcCer was raised by inhibition of GlcCer glucosidase. produced a decretse in $\beta$-glucuronidase of cultured cells [22] and mouse liver and brait [14]. Perhaps the level of Glacer affects only one of the intracellular forms of this enzyme,

Our discovery (Table I) that the concentration of CDH was lowered by D.1.-PDMP is of interest as it was previously found. with cultured cells, that L.PDMP raised the $\mathrm{CDH}$ level considerably $[3,6]$. It is possible that the latter effect is related to the degree of cellular confluency and would not be seen in intact animals. A marked rise in $\mathrm{CDH}$ synthesis has been reported to occur as cells come into contact with one another [29].

While kidney was more sensitive than brain or liver to the side-effects of glucosphingolipids depletion. the changes do not seem to be greal enough to produce 
adverse effects if PDMP were to be administered to patients with genetic disorders of glucosphingolipids accumulation (Gaucher, Tay-Sachs, Fabry, gangliosidosis). Additional disorders that might benefit from glucosphingolipids depletion are: (a) infectious diseases in which the pathogenic organism is known to bind to giucosphingolipids (see Ref. 30); and (b) cancer. in which glucosphingolipids appear to play critical roles [31]. Mice treated with PDMP for 10 days recovered their growth curve quite nicely [5] and, in the case of mice that had been cured of Ehrlich ascites carcinoma, they were found to be immune to reinoculation with these cells. Thus. PDMP treatment does not seem to harm the immunoprotective system.

\section{Acknowledgments}

This investigation was supported by USPHS grants NS-03192 and HD-0740s. We are grateful for laboratory assistance by Inez Mason.

\section{References}

1 Vunnam, R.R. and Radin, N.S. (1980) Chem. Phys, Lipids 26. $265-278$

2 Inokuchi, J. and Radin, N.S. (1987) J. Lipid Res. 38, 565-571.

3 Inokuchi. J.. Momosaki, K., Shimeno, H., Nagamatsu, A. and Radin. N.S. (1989) J. Cell. Physiol. 141, 573-583.

4 Felding-Hahermann, B.. Igarashi. Y., Fenderson, B.A.. Park, L.S., Radin, N.S., Inokuchi, J., Strassmann, G., Handa, K. and Hakomori. S. (1990) Biochemistry 29, 6314-6322.

5 Inokuchi. J., Mason. 1. and Radin. N.S. (1987) Cancer Lett. 38. 23-30.

6 Inokuchi, J., Jimbo, M., Momosaki, K., Shimeno, H., Nagamatsu, A. and Radin. N.S. (1990) Cancer Res. 50, 6731-6737.

7 Gross. S.K.. Shea. T.B. and McCluer, R.H. (1985) J. Biol. Chem. 260. 5033-5039.

8 Sundaram. K.S. and Lev, M. (1984) J. Neurochem. 42, 577-581.

9 Lev, M. and Sundaram, K.S. (1987) New Engl. J. Med. 317, 572.
10 Radin. N.S. and Klinger. P. (1986) Comput. Appl. Biosci. 2. 107- 309.

11 Dinur. T., Grabowski. G.A. Desnick. R.J. and Gatt S (1584) Ana!. Biochem. 136, 223-234.

12 Zeigler, M., Zlotogra, J., Regev, R., Dagan. A., Gatt, S. and Bach. G. (1984) Clin. Chim. Acta 142. 313-318.

13 Gal. A.E. Brady, R.O.. Hibbert, S.R. and Pentchev, P.G. (1975) New Engl. J. Med. 293, 632-636.

14 Hara, A. and Radin, N.S. (1979) Biochim. Biophys. Acta 582, $423-433$.

15 Shukla. G.S. and Radin. N.S. (1990) Arch. Binchem. Biophys. 283. 372-378.

16 Hara. A. and Radin. N.S. (1978) Anal. Biochem. 90, 420-426.

17 Touchstone, J.C.. Levin, S.S., Dohhins, M.F.. Matthews, L., Beers, P.C. and Gabbe, S.G. (1983) Clin. Chem. 29, 1951-1954.

18 Hara. A. and Taketomi. T. (1975) J. Biochem. (Japan) 78. 527-536.

19 Ford-Holevinski. T.S. and Radin. N.S. (1985) Anal. Biochem. 150. 359.363.

20 Datta. S.C. ano Radin. N.S. (1986) Lipids 21. 702-709.

21 Kanfer, J.N., Legler, G., Sullivan. I.. Raghavan, S.S. and Mumford, R.A. (1975) Biochem. Biophys. Res. Commun. 67, 85-90.

22 Dawson, G., Stoolmiller, A.C. and Radin, N.S. (1974) J. Biol. Chem. 249, 4638-4646.

23 Barranger. J.A. and Ginns, E.I. (1989) Glucosylceramide lipidosis: Gaucher disease, in The Metabolic Basis of Inbsrited Disease (Scriver, C.R., Beaudet, A.L., Sly, W.S. and Valle, D., ed.), 6th Edn.. pp. 1677-1698, McGraw-Hill, New York.

24 Hospattankar, A.V., Vunnam, R.R. and Radin, N.S. (1982) Ljpids $17,538-543$.

25 Williams, R.D. Sgoutas, D.S., Zaatari, G.S. and Santoianni, R.A. (1987) J. Lipid Res. 28, 1478-1481.

26 Shayman, J.A., Mahdiyoun, S., Deshmukh, G., Barcelon, F., Inokuchi, J, and Radin, N.S. (1990) J. Biol. Chem. 265. 12135-12138.

27 Morimoto, S.. Yamamoto, Y., O'Brien, J.S. and Kishimoto, Y. (1990) Proc. Natl. Acad. Sci. USA 87, 3493-3497.

28 Yatziv, S., White, M. and Elcor, A. (1974) Thromb. Diath. Haemorrh. 32, 665-669.

29 Marchase, R.B., Rivera, A.A., Land, M.C. and Bull, C.A. (1988) J. Cell Biol. 107. 9a.

30 Karisson, K.-A. (1989) Annu. Rev. Biochem. 58, 309-350.

31 Radin. N.S. and Inokuchi, J. (1988) Biochem. Pharmacol. 37. 2879-2886 